Revue bibliographique pour le domaine irano-aryen

\title{
Mara Nicosia. "Christianity in the Gulf: Vestiges of the East Syrian Presence in Late Antiquity"
}

\section{Florence Jullien}

\section{(2) OpenEdition \\ 1 Journals}

\section{Édition électronique}

URL : https://journals.openedition.org/abstractairanica/54222

DOI : 10.4000/abstractairanica.54222

ISSN : 1961-960X

Éditeur :

CNRS (UMR 7528 Mondes iraniens et indiens), Éditions de l'IFRI

\section{Référence électronique}

Florence Jullien, « Mara Nicosia. "Christianity in the Gulf: Vestiges of the East Syrian Presence in Late Antiquity" ", Abstracta Iranica [En ligne], Volume 42-43 | 2021, document 36, mis en ligne le 30 décembre 2021, consulté le 12 décembre 2022. URL : http://journals.openedition.org/ abstractairanica/54222 ; DOI : https://doi.org/10.4000/abstractairanica.54222

Ce document a été généré automatiquement le 12 décembre 2022.

Tous droits réservés 


\section{Mara Nicosia. "Christianity in the Gulf: Vestiges of the East Syrian Presence in Late Antiquity"}

Florence Jullien

\section{RÉFÉRENCE}

Mara Nicosia. "Christianity in the Gulf: Vestiges of the East Syrian Presence in Late Antiquity" in C. Coppini, F. Simi (eds.). Broadening Horizons 5 : Civilizations in Contact. Proceedings of the 5th "Broadening Horizons" Conference (Udine 5-8 June 2017). III. Interactions and New Directions in Near Eastern Archaeology. Trieste: Edizioni Università di Trieste, 2020, p. 371-383. ISBN: 978-88-5511-048-8, (West \& East. Monografie 4)

1 La présence des communautés chrétiennes syriaques orientales dans la province ecclésiastique du Bēth-Qațrāyē est ancienne, et se développa entre le IVe et le IXe s. L'A. effectue une synthèse des données connues depuis les études du P. Fiey, du P. Steve, de J. Healey, d'Y. Calvet, de J. Beaucamp et C. Robin, de R. A. Carter pour ne citer que les plus marquantes, en tenant compte aussi des parutions des rapports de fouilles notamment de Failaka (à partir de 1991-) et spécialement celles de Khārg (2003). Est rappelée une fois encore l'hétérogénéité relative entre les sources littéraires, parmi lesquelles les actes des synodes offrent le plus d'informations, et les données archéologiques. Sur la langue du Bēth-Qațrāyē étudiée par R. Contini (2003), rappelons qu'au monastère de Rabban-Šābuhr, les moines avaient élaboré une méthode exégétique consistant à proposer des interprétations étymologiques de termes bibliques à partir de mots issus du vocabulaire local qațāyā. 


\section{AUTEURS}

FLORENCE JULLIEN

CNRS, CeRMI, Paris 